\title{
Comparative Histological, Histochemical and Ultrastructure Studies on the Exocrine Pancreas of Japanese Quail (Coturnix coturnix japonica) and Cattle Egret (Bubulcus ibis)
}

\author{
Omaima AYehia*, Yasmine H Ahmed, Ebtihal MM Elleithy, Thorya F Salam and El-Gharbawy SMS \\ Department of Cytology and Histology, Faculty of Veterinary Medicine, Cairo University, Egypt \\ *Corresponding author: omaima.ahmed94@gmail.com
}

Article History: 20-187 Received: 03-Sep-20 Aevised: 05-Dec-20 Accepted: 12-Dec-20
ABS T RA C T
The current study targeted to compare between the pancreas (exocrine part) of Japanese quail and Cattle egret. The
pancreas was investigated in eight apparent healthy mature female Japanese quail and eight Cattle egret. Histological,
histochemical, and ultrastructure studies were carried out. In both birds, the pancreas is located on the right side of the
abdomen between the ascending and descending loops of the duodenum. The pancreas of the Japanese quail composed
of dorsal, ventral, third, and splenic lobes, while in Cattle egret the pancreas is not lobulated. The Exocrine portion
consists of serous acini and intercalated duct, intralobular duct, interlobular duct, and main duct. The duct system was
similar in both birds with minor differences. The intralobular duct in the Cattle egret is characterized by the presence of
serous glands within its wall. Under electron microscopy, the acinar cells were of two types, electron-dense, and
electron-lucent acinar cells. Histochemically, the interlobular duct of the Cattle egret positively reacted to alcian blue
(pH1) and aldehyde fuchsin stains but the interlobular duct of the Japanese quail was negatively reacted.

Key words: Japanese quail, Cattle egret, Histology, Ultrastructure and Histochemistry.

C2020 IJVS - All Rights Reserved

\section{INTRODUCTION}

The Japanese quail (Coturnix coturnix japonica) is a member of the family Phasianidae, order Galliformes, class Aves. It is a granivorous bird feeding on grass seeds (Gross et al. 2020). It is distributed in Africa the in area of the Nile River Valley extending from Kenya to Egypt (Pappas 2013). Quails are utilized as a valuable source of meat and eggs with a belief in their medicinal properties (Nasar et al. 2016). The rapid increase of the economy and the growth of the population with rising health issues accelerate the global need for poultry meat. The growth period of Japanese quail life is a crucial time in appreciating the longterm high performance (Elnesr et al. 2019). They had shorter generation intervals which provide a gainful investment (Sreeranjini et al. 2010). Japanese quail had been used in different research fields as a laboratory animal (Ainsworth et al. 2010).

However, the Cattle egret (Bubulcus ibis) is a species of egrets or heron (family Ardeidae) lived in aquatic habitats worldwide (Kushlan and Hancock 2005). It is an omnivorous bird, feeds on insect-preys, spiders, earthworms, and other invertebrates, and is locally distributed in the Nile delta and Valley (Meese 2012).
Moreover, Goutner et al. (2001) observed that cattle egret commonly breeds in the Nile delta in the Mediterranean region. The cattle egret is considered economically important for farmers as it plays an important role in controlling pests of land and parasites of cattle (Khalifa 2014). However, the overgrowth of their population may compete with and predate the native species (Marcio et al. 2018). They consider free-living birds to act as a reservoir for many diseases (Hussein and Rezk 2016).

The pancreas of a bird has a double function as an organ with both exocrine and endocrine cell types as in mammals. The exocrine tissue consists of the bulk of the pancreatic mass; it secretes digestive enzymes that pass through the duct system to be delivered to the duodenum (Gülmez et al. 2003). Unique cell types of acini and islets secrete enzymes with a digestive role and hormones with a metabolic activity (Cigliola et al. 2015).

None of the available literature was dealing with the Cattle egret pancreas. Moreover, there was a paucity of studies on the Japanese quail pancreas. Therefore, the objective of this investigation is to investigate the histological, histochemical, and ultrastructural features of the exocrine pancreas of Japanese quail as a model of a granivorous bird and Cattle egret as an omnivorous bird.

Cite This Article as: Yehia OA, Ahmed YH, Elleithy EMM, Salam TF and El-Gharbawy SMS, 2021. Comparative histological, histochemical, and ultrastructure studies on the exocrine pancreas of Japanese quail (Coturnix coturnix japonica) and Cattle egret (Bubulcus ibis). International Journal of Veterinary Science 10(2): 107-113. https://doi.org/10.47278/journal.ijvs/2020.030 


\section{MATERIALS AND METHODS}

\section{Collection of Samples}

This work was carried on the pancreas of eight healthy mature female Cattle egret from El Mansoria and Abu Roash and eight healthy mature female Japanese quail from the farm of Agriculture of Cairo University.

The pancreas was removed from the duodenum rapidly after slaughtering of the bird under an ethical protocol approved by the animal experimental local ethics committee at Cairo University. Protocol No. Vet $\mathrm{Cu} 20022020142$. The specimens were fixed in $10 \%$ neutral buffered formalin for $48 \mathrm{hrs}$. The fixed samples were dehydrated in an ascending series of alcohol cleared in xylene, and embedded in paraffin wax overnight, and then 4-5um paraffin sections were obtained by a rotatory microtome.

\section{a- Light Microscopic Examination}

The specimens were stained by Hematoxylin and Eosin (H \& E) stain for histological structure, Masson's trichrome stain for collagen and smooth muscle fibers, Gomori's reticulin stain for demonstration of reticular fibers (Bancroft and Gamble 2013).

\section{b- Transmission Electron Microscopy (TEM) \\ Examination}

Small pieces from the pancreas were fixed in $3 \%$ glutaraldehyde. Then examined with a JEOL 1010 transmission electron microscope at the Regional Center for Mycology and Biotechnology (RCMB), Al-Azhar University.

\section{c- Histochemical Examination}

Pancreas slides were stained with periodic acid Schiff (PAS) for the detection of neutral mucopolysaccharides, modified aldehyde fuchsin, and Alcian blue ( $\mathrm{pH} 1)$ to detect sulfated mucopolysaccharides (Bancroft and Gamble 2013).

\section{RESULTS}

\section{Macroscopic Appearance}

The pancreas of both Cattle egret and Japanese quail was located in the right part of the abdomen; between the two loops of the duodenum. In the Cattle egret, the pancreas appeared as an elongated large mass (Fig.1A). While in the Japanese quail, it consisted of four lobes: two main lobes; dorsal and ventral lobes, the ventral one gave the third lobe and small splenic lobe (Fig. 1B\&C).

\section{Light Microscopic Examination}

The pancreas was covered with a delicate connective tissue capsule consisted of collagen and reticular fibers in both birds. This capsule appeared to be thicker and contained abundant collagen fibers in Cattle egret than in Japanese quail (Fig. 2 A\&B). The capsule sent septa dividing the pancreas into lobes and lobules.

The parenchyma consisted of exocrine and endocrine parts (islets of Langerhans) supported by fine reticular stroma. The exocrine unit was comprised of pancreatic acini (tubuloacinar glands) and ducts of different orders between the lobes and lobules. The acini appeared as spherical to oval units composed of a single layer of serous cells which were pyramidal to columnar shaped cells rest on a basal lamina with a narrow lumen. The acinar cells had spherical basally situated lightly stained nuclei with prominent nucleoli. They had basal basophilic cytoplasm and apical acidophilic cytoplasm (Fig. 2 C\&D).

The duct system in both birds is arranged as intercalated ducts, intralobular ducts, interlobular ducts, and the dorsal and ventral main pancreatic ducts that extend to the duodenum.

In both birds, the intercalated duct had an intra-acinar portion. This portion was lined with Centro-acinar cells which were relatively smaller cells, had a pale cytoplasm so they appeared lightly stained than the acini. They were flattened in shape and situated in the center of the lumina
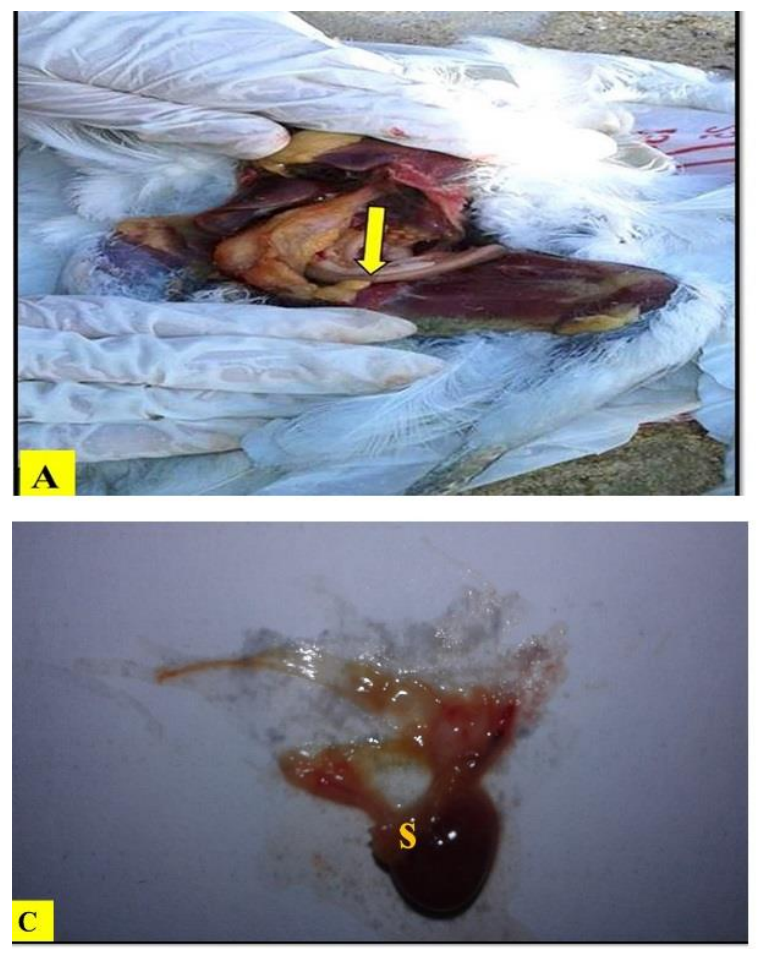

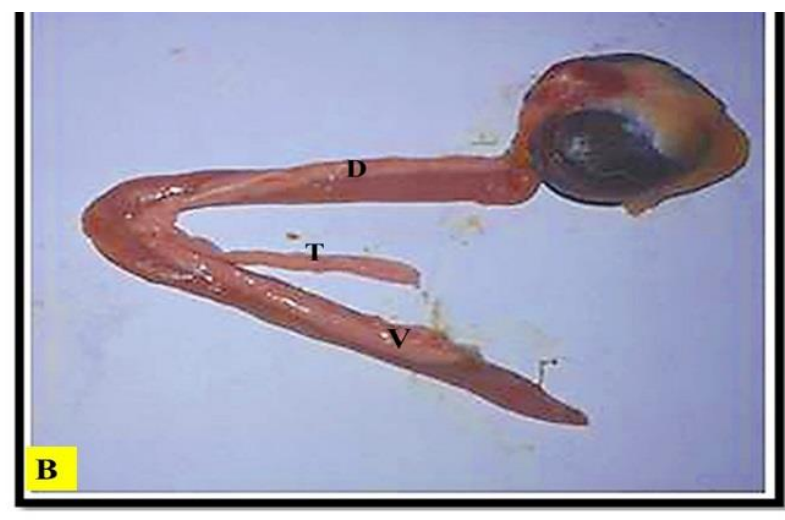

Fig.1: A photograph of the cattle egret non-lobulated pancreas (arrow) between the duodenal loops. B: showing Japanese quail pancreas lobes; the ventral (V), dorsal (D) and third (T). C: showing splenic lobe (S). 

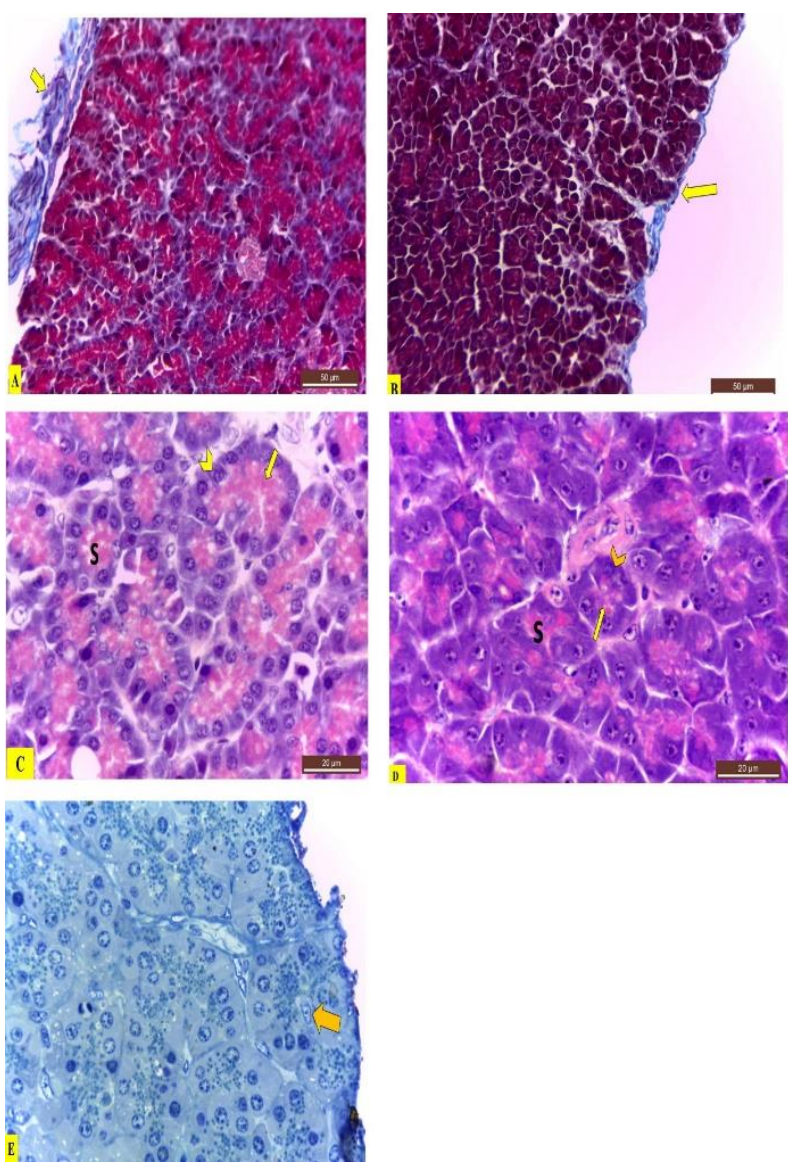

Fig. 2A: Section of cattle egret pancreas showing thick capsule (arrow). B: section of Japanese quail pancreas showing thin capsule (arrow). Masson's Trichrome X400. C: D sections of pancreas showing serous adenomere $(\mathrm{S})$ with apical acidophilic cytoplasm (arrow) and basal basophilic cytoplasm (arrowhead). H\&E X1000. (C) in egret and (D) in Japanese quail. E: Semithin section of cattle egret pancreas showing Centro-acinar cell (arrow). Toluidine blue X1000.

of the acini in front of the apical acidophilic zones (Fig. 2E). They are lined by simple squamous epithelium (Fig. 3 A\&B). This duct continued as a larger intralobular duct; lined by simple cuboidal cells (Fig. 3 C\&D); rested on collagen and reticular fibers (Fig. 3 E\&F).

The interlobular ducts are lined by simple cuboidal epithelium in both birds. Furthermore, in Cattle egret the wall of the interlobular duct contained serous acini (Fig. 4 $\mathrm{A} \& \mathrm{~B})$.

In Cattle egret, the main excretory duct was lined by simple columnar epithelium (Fig.4 C) rested on collagen and reticular fibers contained smooth muscle fibers (Fig.4 D\&E). In Japanese quail, the main duct had the same structure, but the epithelium rested mainly on reticular fibers (Fig. 4F\&G).

\section{Ultrastructure Examination}

The ultrastructural features of pancreatic acini of both birds appeared lined by two types of cells, an electrondense (dark acinar cells) and electron-lucent (light acinar cells) (Fig.5 A\&B). In Cattle egret, the dark cells had spherical nuclei with peripheral clumps of heterochromatin in addition to the presence of numerous spherical and elongated mitochondria with irregular cristae. On the other hand, in Japanese quail, the dark acinar cells contained
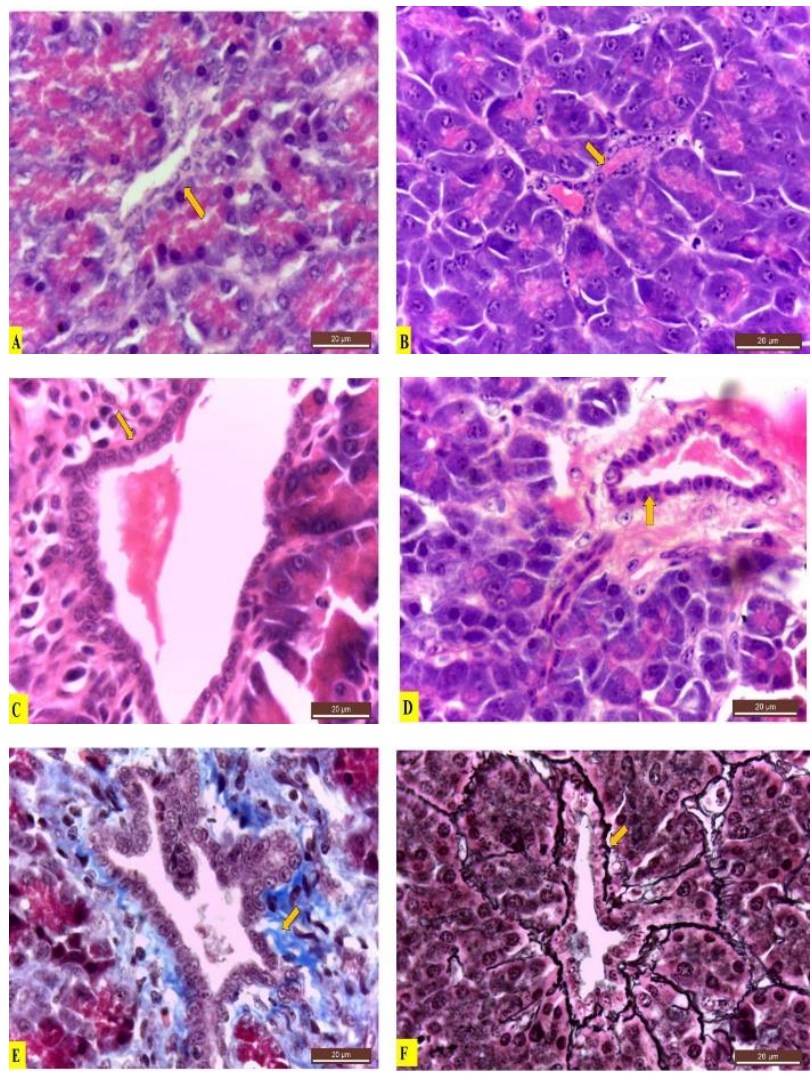

Fig. 3 A: Section of pancreas showing intercalated duct lined by squamous cells (arrow) in cattle egret and B: in Japanese quail. H\&E X1000. C: Section of pancreas showing intralobular duct (arrow) lined by cuboidal cells in cattle egret and D: Japanese quail. H\&E X1000. E: Section of cattle egret pancreas showing intralobular duct supported with collagen fibers (arrow) and $F$ : supported by reticular fibers (arrow). Masson's trichrome X1000 and Gomori's reticulin X1000.

irregular and basally situated nuclei with prominent nucleoli. Moreover, there were numerous mitochondria which appeared mainly spherical in shape. In both birds, there were well-developed laminated cisternae of the rough endoplasmic reticulum (rER) which mainly fill the cytoplasm peri and intranuclear. Numerous zymogen granules of different sizes with electron-dense homogenous content were accumulated in the supranuclear cytoplasm (Fig. 5 C\&D).

The light cells were rarer than the dark cells. In Cattle egret, the light acinar cells had large spherical nuclei with clumped peripheral heterochromatin and smooth nuclear membrane. Their lucent cytoplasm contained intranuclear rER and numerous zymogen granules of variable size. Also, there were numerous large-sized polymorphic mitochondria. In Japanese quail, there was a euchromatic nucleus with prominent nucleoli, in addition to spherical mitochondria and well-developed cisternae of rER (Fig. 5 E\&F).

In both birds, Centro- acinar cells were observed between the acinar cells (Fig.5 B) which differed from the acinar cells by devoid of zymogen granules, their smaller size and being less electron-dense. These cells appeared elongated with scare cytoplasmic organelles and flattened euchromatic nuclei with heterochromatic masses under the nuclear envelope (Fig. 5G\&H). 


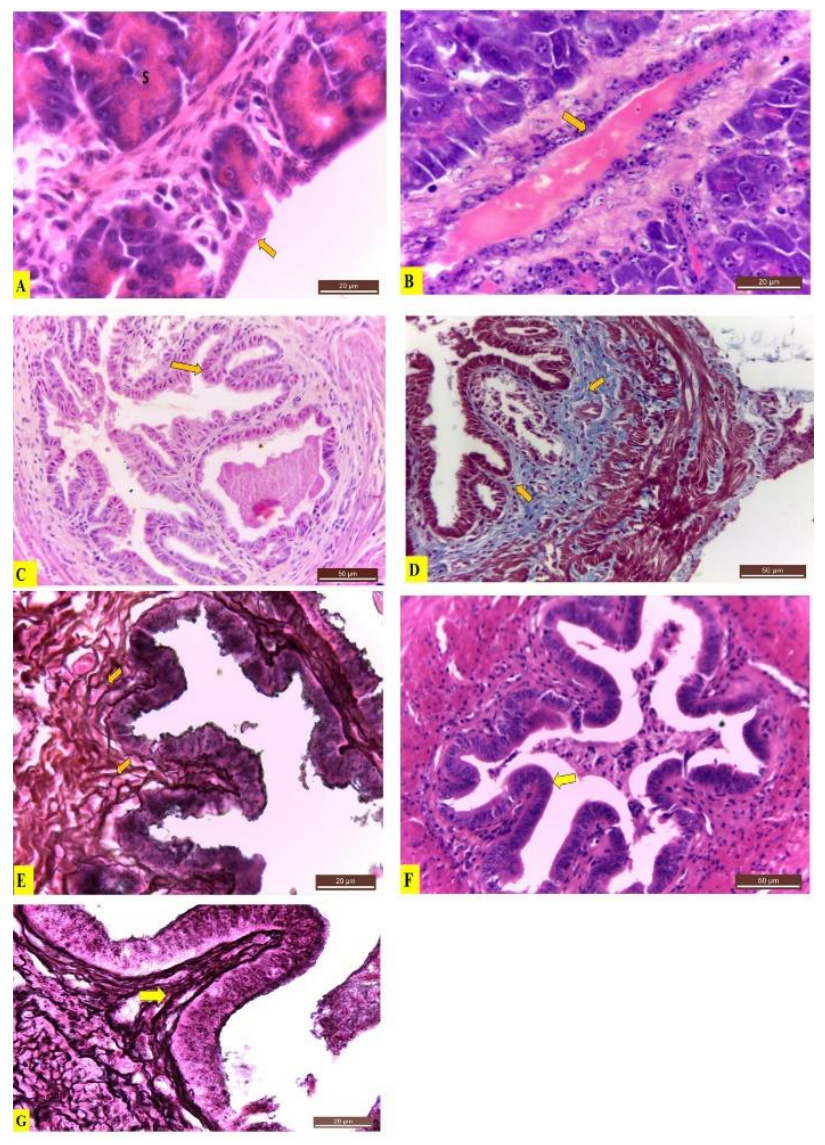

Fig. 4 A: Section of cattle egret pancreas showing interlobular duct lined by cuboidal cells (arrow) with serous acini (SD)within the wall. H\&E X1000. B: Section of Japanese quail pancreas showing interlobular duct lined by cuboidal cells (arrow). H\&E X1000. C: Section of cattle egret pancreas showing the main duct with mucosal folding lined by simple columnar epithelium (arrow) D: supported by collagen fibers and E: reticular fibers (arrow). H\&E X400; Masson's trichrome X400 and Gomori's reticulin X1000. F: Section of Japanese quail pancreas showing the main duct with mucosal folding lined by simple columnar epithelium (arrow) and G: supported by reticular fibers (arrow). H\&E X400 and Gomori's reticulin X1000.

\section{Histochemical Examination}

The apical surface of the epithelial cells lining the interlobular duct of the Cattle egret was positively reacted to alcian blue (pH1) and aldehyde fuchsin stain; so the lumen contained secretory material while the interlobular duct of the Japanese quail was negatively reacted (Fig.6 A\&B). The cells of the main duct in the Cattle egret was PAS-positive while that of the Japanese quail was negatively reacted (Fig. $6 \mathrm{C}$ ).

\section{DISCUSSION}

In Japanese quail and Cattle egret, the pancreas is situated in the right of the abdomen between the two loops of duodenal limbs as reported in common quail (Al-Hathry 2000; Fatlawi 2018), Japanese quail (Şimşek and Alabay 2008), pigeon (Faris 2012). Our results revealed that the pancreas of Cattle egret is non-lobulated while, in Japanese quail, the pancreas is lobulated and consisted of four lobes: dorsal, ventral, third, and splenic lobes. Similar findings were reported by $\mathrm{Ku}$ et al. (2000), Şimşek and Alabay (2008) and Faris (2012) in chicken, Japanese quail, and
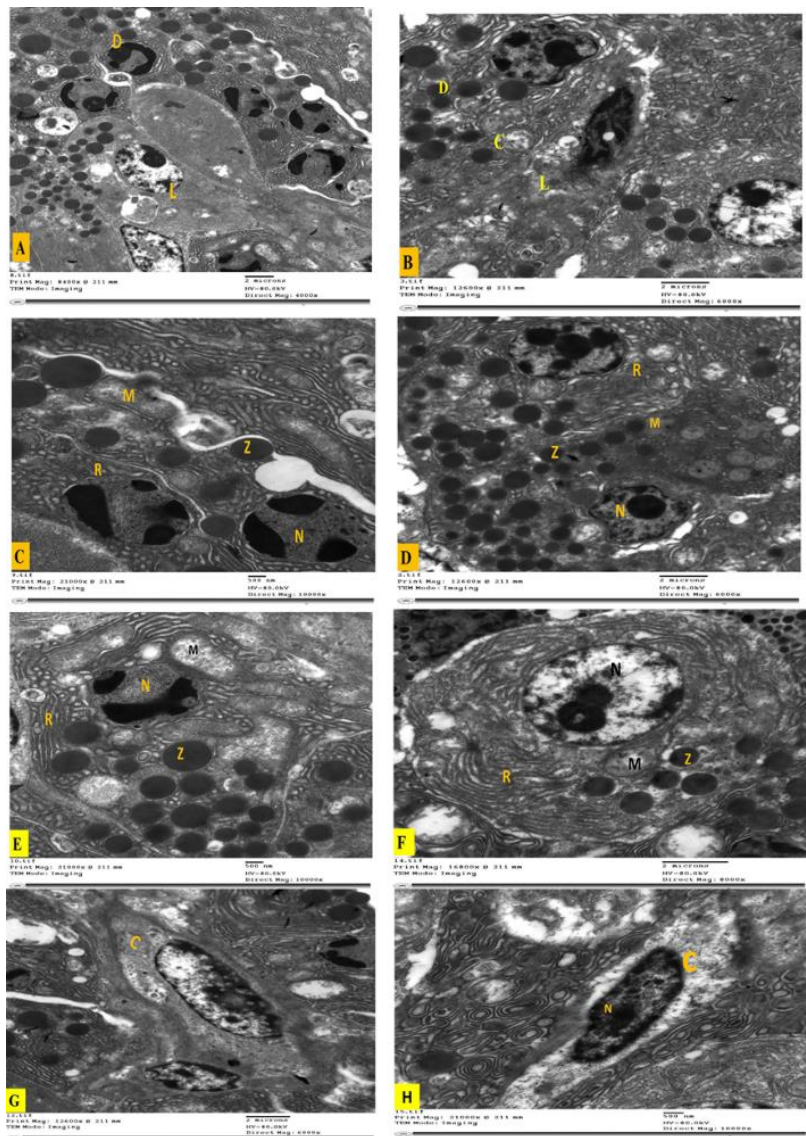

Fig. 5: Transmission electron micrograph showing light (L) and dark acinar cells (D) in A: Cattle egret and B: Japanese quail pancreas. X4000. C: dark acinar cells in cattle egret pancreas showing elongated mitochondria $(\mathrm{M})$, zymogen granules $(\mathrm{Z})$, rough endoplasmic reticulum $(\mathrm{R})$ and spherical nucleus $(\mathrm{N})$. X10000. D: dark acinar cells of Japanese quail pancreas showing spherical mitochondria $(\mathrm{M})$, zymogen granules $(\mathrm{Z})$, rough endoplasmic reticulum (R) and irregular nucleus $(\mathrm{N}) .4000 \mathrm{X}$. E: light acinar cells in cattle egret pancreas: mitochondria(M), zymogen granules(Z), rough endoplasmic reticulum, nucleus(N).10000X. F: light acinar cells in Japanese quail pancreas: mitochondria(M), zymogen granules(Z), rough endoplasmic reticulum, nucleus(N).10000X. G: Centro-acinar cell(C) in cattle egret pancreas 6000X. H: Centro-acinar cell (C) with flattened nucleus (N)in Japanese quail pancreas 10000X.

pigeon, respectively. While Saadatfar et al. (2009) and Şimşek et al. (2009) mentioned that the pancreas of Mynah and falcons composed of three lobes only.

Histologically, the exocrine pancreas of both birds was formed of serous tubulo-acinar glands and the duct system. The acinar cells of both birds are pyramidal to columnar shaped cells which in line with Mobini (2011) in goose and Al-Agele, Mohamed (2012) in golden eagle and Palaskar (2018) in Japanese Quail.These cells characterized by bizonal cytoplasm referred to the presence of acidophilic granules in the apical portion and rich in rER in the basal portion which in agreement with Al-Agele and Mohamed (2012) in golden eagle. However, the hydrolysis of food occurs by the action of the digestive enzymes of the pancreas and the enzymes present on the brush border of intestinal epithelium (Karasov and Hume, 1997). On the other hand, Brzęk et al. (2013) concluded that the activity of pancreatic enzymes in birds is not affected by diet composition. 


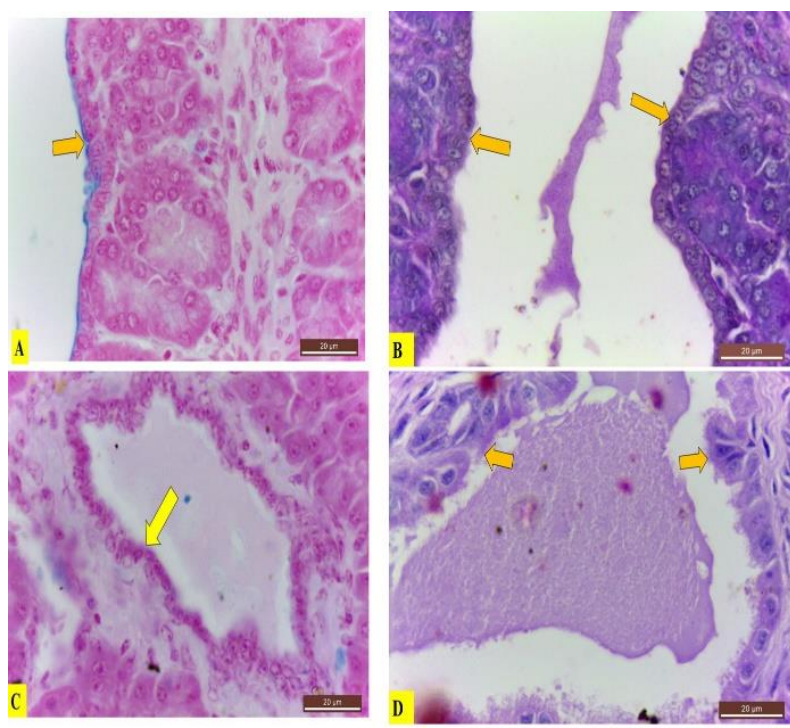

Fig. 6: A Section of cattle egret pancreas showing interlobular duct with Alcian blue (PH1) stain positive reaction (arrow) X1000. B: Section of cattle egret pancreas showing interlobular duct with aldehyde fuchsin stain positive reaction (arrow) X1000.C: Section of Japanese quail pancreas showing interlobular duct with Alcian blue (PH1) stain negative reaction (arrow) X1000 D: Section of cattle egret pancreas showing main duct wtih PAS stain positive reaction (arrow) X1000.

The centro-acinar cells were observed in the lumina of the acini of both birds. These cells were flattened in shape, relatively smaller and brighter without granules than the acinar cells that agreed with Gülmez (2003) in goose; Saadatfar et al. (2011) in dove; Mobini (2011) in goose, Faris (2012) in the pigeon. But the centro-acinar cell is not observed in Mynah (Saadatfar et al. 2009) and Guineafowl and Common gull (Hamodi et al. 2013).

The intercalated ducts in both birds were similar to that described in goose (Gülmez, 2003), and pigeon (Mobini 2013). It is lined with simple squamous epithelium which disagreed with the finding of Al-Hathry (2000) in common quail, Faris (2012) in pigeon, and Mobini (2011) in goose who found that the intercalated duct was lined with simple cuboidal cells.

Moreover, the intralobular ducts which lined by simple cuboidal cells in both birds were found to be similar to that described by Şimşek and Alabay (2008) in Japanese quail, Al-Hathry (2000) in common quail; Al-Shaeli (2010) in duck; Faris (2012) in pigeon; Beheiry et al. (2018) in goose. While in falcon, it is lined with simple squamous epithelium (Şimşek et al. 2009) and with tall columnar epithelium in goose (Gülmez 2003).

In both birds, the interlobular ducts were lined with simple cuboidal epithelium which disagreed with the findings of Al-Hathry (2000) in common quail, Gülmez (2003) in goose, Şimşek and Alabay (2008) in Japanese quail, and Faris (2012) in the pigeon who stated that the interlobular ducts were lined with simple columnar epithelium. Moreover, Hamodi et al. (2013) in Guinea fowl mentioned that the interlobular ducts were lined by simple squamous to cuboidal cells.

In Cattle egret the wall of the interlobular duct contained serous glands in the connective tissue which come in contact with the results of Gülmez (2003) and Mobini (2011) in goose, but these glands were not observed in the duct of Japanese quail which agreed with the finding of Şimşek and Alabay (2008) in Japanese quail and Mobini (2013) in the pigeon.

Our result for both birds showed that the main excretory ducts were lined by a simple columnar cell. In contrast, Al-Sharoot (2016) in goose described that the main duct was lined by simple to stratified columnar cells while Beheiry et al. (2018) in goose described that the main duct was lined by stratified cuboidal to stratified columnar epithelium. Moreover, the connective tissue around the main ducts contains thick layers of smooth muscle fibers which is in accordance with Deprem et al. (2015) in goose.

As reported by Şimşek and Alabay (2008) in Japanese quail on the ultrastructure of the acini, our results for both birds distinguished the acinar cells as dark cells (electrondense) and light cells (electron-lucent). The electron-lucent acinar cells of both birds have spherical euchromatic nuclei, many ribosomes, and rER in the basal region in agreement with Şimşek and Alabay (2008) in Japanese quail. Many rod-shaped mitochondria in cattle egret while spherical in Japanese quail. Meanwhile, Beheiry et al. (2018) in goose observed numerous polymorphic mitochondria. These light cells are thought to be active cells as mentioned by (Şimşek and Alabay 2008). While the dark cells characterized by dense cytoplasm comprised different intensities of zymogen granules, mitochondria, and rER with heterochromatic nuclei. The presence of dense zymogen granules in both birds with similar secretion supports the finding of Beheiry et al. (2018) in goose.

Centro-acinar cells are less electron-dense with euchromatic flattened nuclei. These cells differ from the acinar cells by lacking zymogen granules, their smaller size, scare cytoplasmic organelles that in line with Şimşek and Alabay (2008) in Japanese quail; Mescher (2010) and Beheiry et al. (2018) in goose.

Histochemically, the apical surface of the luminal border of interlobular ducts cells of cattle egret were aldehyde fuchsin and alcian blue $(\mathrm{pH} \mathrm{1})$ positive. This indicates the presence of sulfated mucins which agrees with Gülmez (2003) in goose but this duct in Japanese quail showed a negative reaction.

The epithelium of the main duct in the Cattle egret is characterized by PAS-positive granules as reported by Stornelli et al. (2006) in ostrich; Şimşek et al. (2009) in falcon; Kadhim et al. (2010) in red jungle fowl and Deprem et al. (2015) in goose. The presence of neutral mucosubstances may help the protection of the epithelium and the transportation of pancreatic secretion as mentioned by Deprem et al. (2015). Zharkov et al. (1994) mentioned that the features of the epithelial mucous in the pancreatic duct are found to be different depending on the type of the digested food.

\section{Conclusion}

The quail pancreas is divided into the dorsal, ventral, third and splenic lobes while the cattle egret pancreas is non-lobulated. The structure of the pancreas in the cattle egret and the Japanese quail was found to be similar except for the interlobular duct in the cattle egret which contains a gland within its wall. Ultra-structurally, the secretory acini in both birds were formed of dark and light cells with Centro-acinar cells. Histochemically, the lining of the 
interlobular duct in the cattle egret was positive for modified aldehyde fuchsin and Alcian blue (PH1). Also, the main duct was reacted positively with PAS stain. But the interlobular duct and main duct of the Japanese quail were negatively reacted to these stains.

\section{REFERENCES}

Ainsworth SJ, Stanley RL and Evan DJR, 2010. Developmental stages of the Japanese quail. Journal of Anatomy 216: 3-15. https://doi.org/10.1111/j.1469-7580.2009. 01173.

Al-Agele RAA and Mohammed FS, 2012. Architecture morphology and histological investigations of pancreas in golden eagles (Aquila chrysaetos). Al Anbar Journal of Veterinary Science 5: 149-155.

AL-Hathry SA, 2000. Topographical, Histological and Histochemical study of the pancreas of Common Quail (Coturnix C. Coturnix L.) M.Sc. Thesis University of Baghdad- Baghdad, Iraq. pp: 47-48.

Al-Shaeli SJ, 2010. Anatomical and histological study of the pancreas in local breed ducks (Anas platyrhnchos, Mallard) (Doctoral dissertation, M.Sc. Thesis, College of Veterinary Medicine. The University of Baghdad-Iraq.

Al-Sharoot HA, 2016. Anatomical, histological and histochemical architecture of pancreases in early hatched goose (Anser anser). Kufa Journal for Veterinary Medical Sciences 7: 147-153.

Bancroft JD and Gamble M, 2013. Theory and practice of histological techniques. 7th Ed. Churchill Livingstone /Elsevier, Oxford, UK. pp:173-179 and 363-39.

Beheiry RR, Abdel-Raheem WA, Balah AM, Salem HF and Karkit MW, 2018. Morphological, histological, and ultrastructural studies on the exocrine pancreas of goose. Beni-Suef University Journal of Basic and Applied Sciences 7: 353-358. https://doi.org/10.1016/j.bjbas.2018.03.00.

Brzęk P, Ciminari ME, Kohl KD, Lessner K, Karasov WH and Caviedes-Vidal E, 2013. Effect of age and diet composition on the activity of pancreatic enzymes in birds. Journal of Comparative Physiology B. 183: 685-697. https://doi.org/10.1007/ s00360-012-0731-2.

Cigliola V, Allagnat F, Berchtold LA, Lamprianou S, Haefliger JA and Meda P, 2015. Role of Connexins and Pannexins in the Pancreas. Pancreas 44: 1234-44. https://doi.org/10.1097/MPA. 0000000000000378.

Deprem T, Tasci SK, Bingol SA, Sari EK, Aslan S and Ilhan S, 2015. Histological and histochemical studies on the structure of pancreatic ducts of goose. Turkish Journal of Veterinary and Animal Science 39: 62-68. https://doi.org/10.3906/vet1408-19

Elnesr SS, Ropy A and Abdel-Razik AH, 2019. Effect of dietary sodium butyrate supplementation on growth, blood biochemistry, hematology and histomorphometry of intestine and immune organs of Japanese quail. Animal, 13: 1234-1244. https://doi.org/10.1017/S1751731118002732

Faris SA, 2012. Anatomical and Histological Study of the Pancreas of Pigeon. Journal of College of Education, ThiQar University, Iraq 2: 64-72.

Fatlawi DJA, 2018. Morphological and histological study of the pancreas of quail (Coturnix coturnix). Journal of Global Pharma Technology 10: 125-128.

Goutner V, Furness W and Papakostas G, 2001. Mercury in feathers of Squacco heron (Ardeolaralloides) chicks in relation to age, hatching order, growth, and sampling dates. Environmental Pollution 111: 107-115. https://doi.org/ 10.1016/S0269-7491(99)00329-2.

Gülmez N, 2003. Are glands present in Goose pancreatic Ducts? Alight microscope study. Journal of the Pancreas 4: 125-128.

Gross MS, Bean TG, Hladik ML, Rattner BA and Kuivila KMJ, 2020. Uptake, metabolism, and elimination of fungicides from coated wheat seeds in Japanese Quail (Coturnix japonica) Journal of Agriculture and Food Chemistry 68: 1514-1524. https://doi.org/10.1021/acs.jafc.9b05668

Hamodi MH, Abed AA and Taha AM, 2013. Comparative anatomical, histological and histochemical study of the pancreas in two species of birds. Research \& Reviews in Bio Sciences 8: 26-34.

Hussein S and Rezk H, 2016. Macro and microscopic characteristics of the gastrointestinal tract of the Cattle Egret (Bubulcus Ibis). International Journal of Anatomy and Research 4: 2162-2174. https://doi.org/10.16965/ijar.2016. 169.

Kadhim KK, Zuki ABZ, Noordin MM, Babjee SMA and ZamriSaad M, 2010. Morphological study of the pancreatic duct in red jungle fowl. African Journal Biotechnology 9: 7209-7215. https://doi.org/10.5897/AJB10.934

Karasov WH and Hume ID, 1997. The vertebrate gastrointestinal system. In: Dantzler WH (ed): Handbook of Physiology, section 13: Comparative Physiology, vol 1. Oxford University Press, New York, pp: 407-480. https://doi.org/ 10.1002/cphy.cp130107.

Khalifa EF, 2014. Gross anatomical studies on the celiac artery in cattle egret (Bubulcus ibis) with special reference to the arterial supply of the stomach. Journal Veterinary Anatomy 7: 1-13. https://doi.org/10.21608/jva.2014.44711.

Kushlan JA and Hancock JA, 2005. The Herons. Oxford University Press, New York, NY, USA.

Ku SK, Lee JH and Lee HS, 2000. An immunohistochemical study of the insulin-, glucagon- and somatostatinimmunoreactive cells in the developing pancreas of the chicken embryo. Tissue and Cell Journal 32: 58-65. https://doi.org/10.1054/tice.1999.0086.

Marcio A Silva, Érika FST Fernandes, Sandra C Santana, Maria Fernanda V Marvulo, Mércia R Barros, Sineide MO Vilela, Eliane MF Reis, Rinaldo A Mota and Jean CR Silva, 2018. IIsolation of Salmonella spp. in cattle egrets (Bubulcus ibis) from Fernando de Noronha Archipelago, Brazil. Brazilian Journal of Microbiology 49: 559-563. https://doi.org/ 10.1016/j.bjm.2018.01.004.

Meese RJ, 2012. Cattle egret predation causing reproductive failures of nesting tricolored blackbirds. California Fish and Game Journal 98: 47-50.

Mescher AL, 2010. Junqueira's Basic Histology, 12th ed. The Mc Graw-Hill Companies. Inc. Ch. 16: 285-286 \& Ch. 20: 359.

Mobini B, 2011. Histological studies on the pancreas of goose (Anser albifrons). Veterinary Research Forum 2: 25-29.

Mobini B, 2013. Histochemical and histological studies on the pancreas of mature pigeon (Columba Livia). European Journal of Experimental Biology 3:148-152.

Nasar A, Rahman A, Hoque N, Kumar Talukder A and Das ZC, 2016. A survey of Japanese quail (Coturnix coturnix japonica) farming in selected areas of Bangladesh. Veterinary World Journal 9: 940-947. https://doi.org/ 10.14202/vet world.2016.940-947

Palaskar MS, 2018. Age-Related Histomorphological and Histochemical Studies on Pancreas in Japanese Quail Coturnix coturnix japonica. MVSc MAFSU, Nagpur. p:174

Pappas J, 2013. "Coturnix japonica". Animal Diversity Web. Retrieved 20 October2013.

Saadatfar Z and Asadian M, 2009. Anatomy of the pancreas in Mynah (Acridotheretristis). Journal of Applied Anima Research 36: 191-193. https://doi.org/10.1080/09712119. 2009. 9707057.

Saadatfar Z, Asadian M and Alishahi, E, 2011. Structure of pancreas in Palam Dove (Streptoplia selegalensis). Iranian Journal of Veterinary Science and Technology 3: 25-32.

Şimşek N and Alabay B, 2008. Light and electron microscopic examinations of the pancreas in quails (Coturnix coturnix japonica). Revue de Medicine Veterinaire Journal 4: 198206. 
Int J Vet Sci, 2021, 10(2): 107-113.

Şimşek N, Bayraktaroğlu AG and Altunay H, 2009. Localization of insulin immunopositive cells and histochemical structure of the pancreas in falcons (Falco anaumanni). Ankara Üniversitesi Veteriner Fakültesi Dergisi 56: 241-247.

Sreeranjini AR, Iyyangar MP and Pramodkumar D, 2010. Histological study on the fibrous architecture of kidney and ureter of Japanese quail (Coturnix coturnix japonica). Tamilnadu Journal of Veterinary Animal Science 6: 107110.
Stornelli MR, Ricciardi MP, Miragliott V, Coli A and Giannessi E, 2006. Morphostructural study of the pancreas and pancreatic duct in ostrich (Struthio camelus L.). Acta Veterinaria Brno journal 75: 157-160.

Zharkov VP, Yarygin VN and Dolzhikov AA, 1994. Structural basis for an epithelial barrier in the main pancreatic duct of some mammals. Bulletin of Experimental Biology and Medicine 118: 1211-1213. https://doi.org/10.1007/ BF02444628. 